\title{
Glioblastoma by Gene Expression Profile
}

National Cancer Institute

\section{Source}

National Cancer Institute. Glioblastoma by Gene Expression Profile. NCI Thesaurus. Code C111691.

Classification of glioblastoma into molecular subtypes as defined by gene expression profiling. 